\title{
A CONSTRUÇÃO DA IMAGEM DOS "OUTROS" SUJEITOS URBANOS NA ELABORAÇÃO DA NOVA VISUALIDADE URBANA DE PORTO
}

ALEGRE NOS ANOS $1950^{1}$

\section{Charles Monteiro²}

Pontifícia Universidade Católica do Rio Grande do Sul

Um levantamento das fotorreportagens sobre a cidade de Porto Alegre na Revista do Globo nos anos 1950 permite apontar um grande número de matérias sobre o processo de crescimento urbano e verticalização, bem como o papel estratégico dessa revista na construção de uma imagem e de um imaginário moderno de cidade. Um grupo menor de fotorreportagens aborda a modernização das formas de sociabilidade, outro ainda mais reduzido trata da persistência de práticas tradicionais e da presença de sujeitos desviantes no espaço urbano, que constituíam o avesso desse projeto de modernização da sociedade porto-alegrense.

O objetivo do trabalho é problematizar a construção da imagem desses "outros" sujeitos urbanos, aqui particularmente representados pelos jovens e pelas crianças em situação de rua. Estes "outros" não eram considerados como cidadãos-construtores da cidade moderna e constituíam o avesso da nova ordem no processo de elaboração de um novo padrão de visualidade do espaço urbano nas fotorreportagens sobre a cidade de Porto Alegre na Revista do Globo nos anos 1950. Trata-se de um pequeno recorte de uma pesquisa maior sobre as imagens da cidade de Porto Alegre nos anos 1950, que vêm sendo desenvolvida no centro de Pesquisa em Imagem e Som do PPGH da PUCRS e conta com apoio financeiro do CNPq (MONTEIRO, 2007).

A problemática de pesquisa envolve questões acerca da construção de uma nova visualidade urbana e a elaboração de padrões visuais de representação da

\footnotetext{
1 Comunicação apresentada no Simpósio Temático História, Imagem e Cultura Visual na XXIV Simpósio Nacional de História da ANPUH realizado de 15 a 20 de julho de 2007 na UNISINOS (São Leopoldo/RS) e coordenado pelos Profs. Drs. Iara Lis Franco Schiavinatto (UNICAMP) e Charles Monteiro (PUCRS).

2 Doutor em História Social (PUCSP/Université Lumière - Lyon 2) e Professor Adjunto de História do PPGH da PUCRS.
} 
cidade de Porto Alegre na imprensa nos anos 1950, no contexto de uma nova cultura visual (MENESES, 2003, 2005; KNAUS, 2006). Visa-se compreender a construção de significados sociais a partir da produção e da veiculação de imagens fotográficas da cidade de Porto Alegre nos anos 1950 na Revista do Globo. Buscase discutir os temas, as formas de fotografar a cidade e os sujeitos urbanos, 0 processo de editoração dessas imagens fotográficas pela sua inserção em fotorreportagens nas páginas desse veículo de comunicação e o consumo social dessas imagens no período, visando a compreender a nova visualidade urbana e as representações de cidade naquele contexto de crescimento populacional, expansão do perímetro urbano e verticalização da área central ${ }^{3}$.

Em "Rumo a uma 'História Visual'", Meneses propõe que o estudo desse campo se realize a partir da reflexão sobre três domínios complementares: o visual, o visível e a visão (MENESES, 2005: 33-56). O domínio do visual compreenderia os sistemas de comunicação visual e os ambientes visuais, bem como "os suportes institucionais dos sistemas visuais, as condições técnicas, sociais e culturais de produção, circulação, consumo e ação dos recursos e produtos visuais", para poder circunscrever "a iconosfera, isto é, o conjunto de imagens-guia de um grupo social ou de uma sociedade num dado momento e com o qual ela interage" (MENESES, 2005: 36).

Para Meneses, o domínio do visível e o do invisível situa-se na esfera do poder e do controle social, do ver e ser visto, do dar-se a ver ou não dar-se a ver, da visibilidade e da invisibilidade (MENESES, 2005: 36). Já a visão "compreende os instrumentos e técnicas de observação, o observador e sés papéis, os modelos e modalidades do olhar" de uma época (MENESES, 2005: 38).

A Revista do Globo foi a revista ilustrada quinzenal mais duradoura e de maior tiragem no Rio Grande do Sul entre 1930 e 1960. Tendo sido criada em 1929, tornara-se um veículo de comunicação influente na imprensa regional, como um projeto gráfico e editorial arrojado para o período. Nos anos 1950, a Revista do Globo disputava espaço regionalmente com outras revistas de tiragem nacional como O Cruzeiro e Manchete. Todas elas se inspiravam de alguma forma no

\footnotetext{
3 Entre outras pesquisas importantes sobre padrões de visualidade urbana ver especialmente os trabalhos de LIMA \& CARNEIRO (1997); MAUAD (1990, 2005), MICHELON (2001), POSSAMAI (2005).
} 
modelo americano fornecido pela LIFE, publicando fotorreportagens com tom sensacionalista misturadas a artigos de entretenimento, obras literárias (contos, poesias) e a vida social das elites urbanas das principais capitais. A Revista do Globo publicava sempre na capa uma foto colorida de uma moça de destaque da sociedade local e um anúncio publicitário na contracapa. De forma geral, a edição quinzenal costumava possuir cerca de 95 páginas e estava dividida entre as seções: "Reportagens", "Assuntos Gerais", "Literatura", "Cinema" e "Passatempo". As "Reportagens" abordavam assuntos internacionais, nacionais e locais entremeados por publicidades e crônicas visando a dar maior leveza à leitura da revista.

Na Revista do Globo três fotógrafos contratados produziram o maior número das fotorreportagens dos anos 1950: Pedro Flores, Léo Guerreiro e Thales de Farias. Os nomes desses fotógrafos começaram a aparecer abaixo do título como co-autores dessas fotorreportagens. O trabalho deles era complementado por outros fotógrafos free lancers e pelas imagens compradas de agências de informação e outras revistas.

De forma geral, as fotorreportagens da Revista do Globo iniciavam-se com uma fotografia de página inteira ou página dupla, que era uma "imagem síntese" do tema e visava mobilizar emocionalmente a atenção do leitor sobre a matéria (Ver COSTA, 1992: 53-68). Compreender a relação entre imagem e texto é importante no sentido de compreender como este disciplina a leitura daquele. $O$ título e uma legenda sobrepostos à fotografia de grande formato completavam o apelo à atenção do leitor. Seguia-se uma seqüência de cerca de 6 a 12 fotos formando uma narrativa ao redor do tema principal. Pequenos textos e subtítulo auxiliavam na urdidura da trama e na construção dessa narrativa visual, direcionando a atenção do leitor para determinados aspectos da realidade abordada nas fotos.

Entre as 256 edições da Revista do Globo publicadas entre 1950 e 1960, foi possível identificar 184 fotorreportagens que tratavam da cidade de Porto Alegre, pelo levantamento realizado. Essas fotorreportagens abordavam questões relativas ao processo de modernização do espaço urbano (verticalização, obras públicas e privadas), as novas formas de sociabilidade públicas (muitas ligadas aos novos padrões de consumo), os novos equipamentos culturais, problemas de segurança 
pública, de habitação, de transportes e, também, política municipal. A revista valorizava o processo de modernização e alguns dos problemas urbanos de Porto Alegre. Para esse trabalho considera-se apenas uma pequena amostragem desse todo, o diminuto número de fotorreportagens que construíram a imagem dos "outros" sujeitos urbanos que não se enquadram na categoria dos políticos, urbanistas, arquitetos, intelectuais e artistas responsáveis pela construção, gestão e produção da identidade urbana moderna da cidade.

Através de imagens e palavras a revista construiu representações sociais, agregando novidade e promovendo o consenso ao redor de certos significados sociais. Quanto menor a competência na decifração dos códigos verbais, maior a importância das imagens fotográficas que ocupavam a maior parte do espaço das páginas. A imagem funcionava como uma espécie de prova documental de um acontecimento, reafirmando e comprovando os pontos de vista, os valores e os significados sociais construídos pelo discurso verbal (título, subtítulos e texto) da fotorreportagem.

As fotografias participavam do projeto de construção da visualidade urbana e do processo de inclusão e legitimação da ação de certos atores e grupos sociais, bem como da exclusão e estigmatização da ação e presença de outros sujeitos e grupos sociais no espaço urbano em processo de modernização. As fotografias ajudavam a dar visibilidade, davam a ver certos grupos e práticas sociais, bem como construíam hierarquias e diferenças sociais. O processo de construção de identidades ou de identificações sociais, bem seu oposto a alteridade e a exclusão aparecem ora de forma camuflada e ora de forma clara e plasmada em certos sujeitos e grupos sociais. Os "discursos e os sistemas de representação constroem lugares a partir dos quais os indivíduos podem se posicionar e a partir dos quais podem falar" (WOODWARD, 2000: 17ss).

Passo a abordar algumas dessas fotorreportagens que elaboram a representação social dos outros sujeitos urbanos na Revista do Globo nos anos 1950. A primeira delas é Porto Alegre: uma cidade entregue aos ladrões de 21 de fevereiro de 1953 (TAJES; FLORES; CAVALHEIRO, 1953), com três páginas e oito fotografias em P\&B. A fotografia de abertura da fotorreportagem é de grande formato, no sentido horizontal, e ocupa a metade da primeira página. 


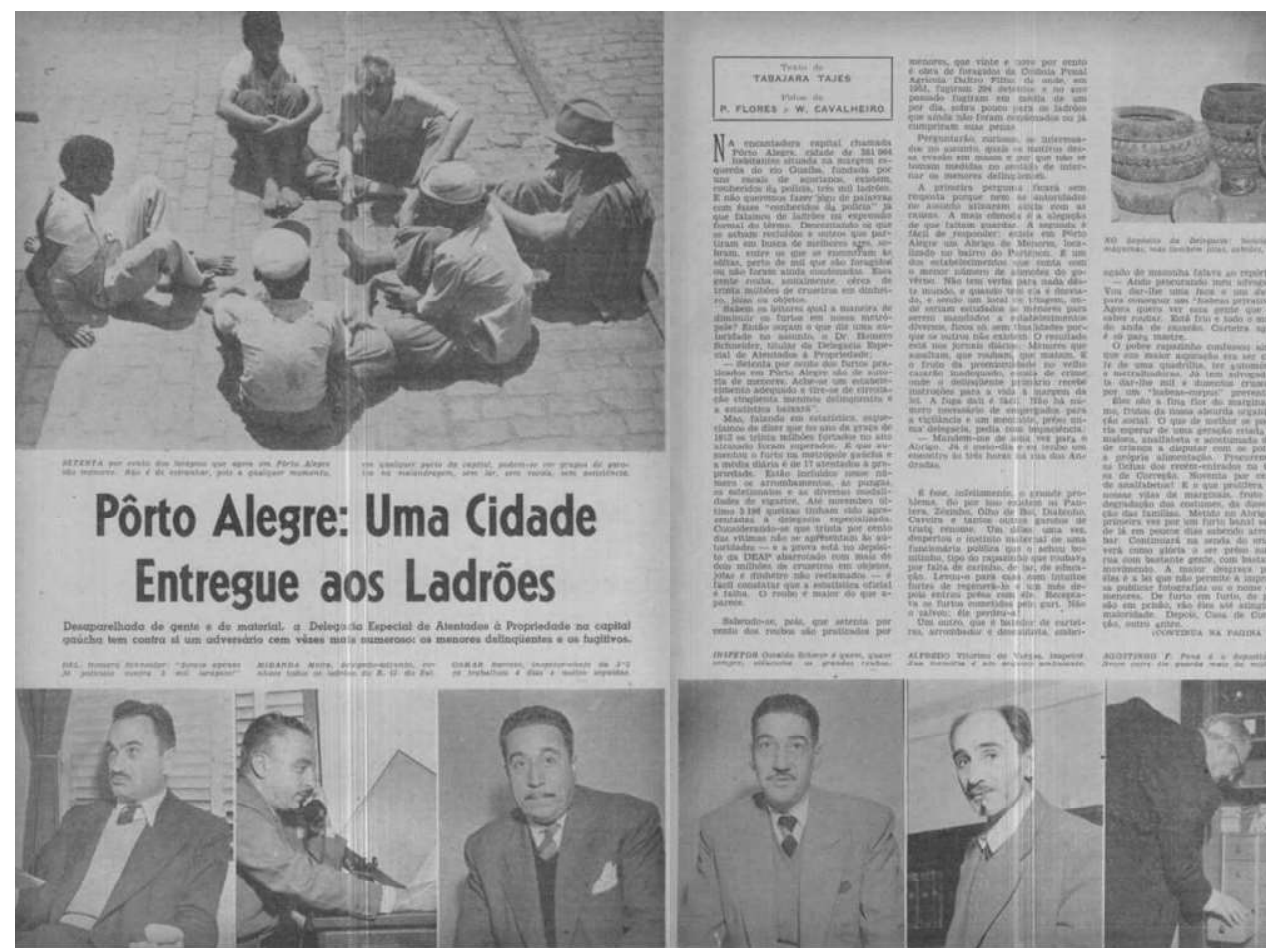

Imagem 1. Fonte: TAJES, T.; FLORES, P.; CAVALHEIRO, W. (1953). Porto Alegre: Uma cidade entregue aos ladrões. In: Revista do Globo, n. 580, 21/02/1953, p. 60, 61.

Nessa primeira imagem são representadas seis crianças descalças, sentadas sobre os paralelepípedos do chão da rua (um trilho de bonde é visível no canto direito) em uma roda. Três delas encontram-se de costas e usam chapéus, uma delas está de perfil e outras duas de frente para câmara, mas não podemos ver seus rostos. Três delas são negras e uma delas tem cabelo claro.

Elas parecem conversar ou jogar, pois estão todas olhando para o centro da roda. A fotografia em P\&B, tirada de cima para baixo, ao nível dos olhos de um adulto, com luz forte do meio dia, salienta os contornos e os volumes. Ao pé da página, três pequenas fotografias no estilo retrato de meio corpo e de formato retangular vertical apresentam três homens sentados de terno e gravata em fotos de interior. O primeiro deles é apresentado em $3 / 4$ sentado, o segundo de perfil sentado fala ao telefone e o terceiro é apresentado frontalmente em frente a uma parede (fundo neutro). O fotografo tira as fotos no mesmo plano dos olhos dos homens fotografados. 
Em uma delas, a fotografia central, é possível identificar que o local é um escritório, pois o homem está sentado atrás de uma escrivaninha e fala ao telefone. A análise da diagramação das fotografias na página da revista aponta para uma oposição/tensão entre a fotografia dos meninos descalços representados acima da página e as fotografias dos três homens de terno e gravata na parte debaixo da página. Essa oposição é construída também no plano formal, pois a primeira fotografia é externa e enquadra um pequeno grupo na rua, enquanto as três fotografias abaixo enquadram planos fechados do interior de um escritório. A primeira é tirada de cima para baixo apontando uma hierarquia do olhar (superioridade do fotógrafo/repórter/adulto que tira a foto) e cortada no formato retângulo horizontal salientando o chão, no qual as crianças encontram-se sentadas, já as outras três fotografias são tomadas da mesma altura dos olhos dos homens de terno e são cortadas em um retângulo vertical (ascensão).

$\mathrm{Na}$ página seguinte, outras quatro fotos de formato pequeno e retangular vertical completam a fotorreportagem. A quarta foto, no canto superior direito, é uma tomada de interior onde aparecem duas pilhas de pneus, uma bicicleta encostada e alguns objetos menores de difícil identificação (a legenda explica tratar-se de objetos apreendidos pela ação da polícia). As três fotos em baixo da página também são retratos de três homens, dois de terno e gravata e um de longo casaco preto. O primeiro está sentado e de frente sob um fundo neutro, o segundo em $3 / 4$ de pé e em frente a uma estande com livros e o terceiro de costas e perfil se inclina em frente a um cofre com várias gavetas e pega algo no seu interior. Novamente, há uma oposição entre a foto no canto superior tirada de cima para baixo e as três dos homens tiradas ao mesmo nível dos olhos. As legendas das fotos ampliam essa contradição e aprofundam a tensão social entre esses dois grupos. O primeiro sobre o qual se projeta um olhar externo, que é um ser visto pelo outro, ou seja, a objetiva do repórter fotográfico, e o segundo que é um darse a ver da autoridade policial que olha para a câmera do fotógrafo.

A legenda da primeira foto afirma que "sessenta por cento dos larápios que agem em Porto Alegre são menores" e completa "não é de estranhar, pois a qualquer momento, em qualquer lugar parte da capital, podem-se ver grupos de garotos na malandragem, sem lar, sem escola, sem assistência" (TAJES; FLORES; CAVALHEIRO, 1953: 60). Já as legendas das seis fotos menores de homens de 
terno e gravata indicam que se trata do delegado Homero Schneider, do delegadoadjunto Miranda Meira, do inspetor-chefe Osmar Barreto, dos inspetores Osvaldo Scherer e Alfredo Vitorino Vargas e do depositário Agostinho F. Pena. Todos idividualizados ao serem retratados de perto em seu ambiente de trabalho, no exercício de suas funções e identificados pelo nome, sobrenome e respectivos cargos na polícia. A ordem policial é representada pelos policiais e objetos relacionados ao seu trabalho (telefone, livros, cofre).

A análise do texto da fotorreportagem aponta para o aprofundamento dos binômios delinqüentes versus polícia e desordem versus ordem policial, o que reforça esse processo de hierarquização e estigmatização das crianças de rua através do tom sensacionalistas que caracterizava as revistas ilustradas do período. O subtítulo afirma: "Desaparelhada de gente e de material, a Delegacia Especial de atentados à propriedade na capital gaúcha tem contra si um adversário cem vezes mais numerosos: os menores delinqüentes e os fugitivos" (Id., ib.: 60). A Revista também dá a palavra aos polícias, enquanto se apropria da fala de um dos jovens para construir dele uma imagem de perigoso contraventor: "O pobre rapazinho confessou ainda que sua maior aspiração era ser chefe de uma quadrilha, ter automóvel e metralhadora" (Id.,ib.: 61). Por um lado, o texto salienta a potencialidade do futuro criminoso, por outro, a fala do menino se refere a um signo da modernidade como o "automóvel", que aponta para a pregnância do ideário de modernidade mesmo entre os excluídos e marginalizados.

A estigmatização social desses jovens pela revista se completa ao final da fotorreportagem:

O que de melhor se poderia esperar de uma geração criada na maloca, analfabeta e acostumada desde criança a disputar com os porcos a própria alimentação. Procurem-se as fichas dos recém-entrados na Casa de Correção. Noventa por cento analfabetos! É o que prolifera em nossas vilas de marginais, fruto da desagregação dos costumes, da dissolução das famílias. (Id., ib.: 61)

Acerca da imagem pública dessas crianças e jovens a revista sentencia: "A maior desgraça para eles é a lei que não permite à imprensa publicar fotografias ou o nome dos menores" (Id., ib.: 61). O que explica o fato das fotografias não mostrarem nem os rostos e nem os olhos dos jovens. O que evidencia o desejo social de visibilidade do poder (da polícia), de identificação e de controle desses 
jovens em uma cidade em processo acelerado de crescimento e diversificação social.

A campanha de moralização e controle social do espaço urbano fica clara quando a revista dá a palavra ao inspetor Schneider: "- Sessenta por cento dos furtos praticados em Porto Alegre são de autoria de menores. Ache-se um estabelecimento adequado e tire-se de circulação cinqüenta meninos delinqüentes e a estatística baixará" (Id., ib.: 61).

Ou seja, o ideal policial seria o seu isolamento e a sua vigilância em instituições corretivas para crianças e adolescentes. O que nos leva a outra fotorreportagem da Revista do Globo de 10 de julho de 1954 intitulada Não é doce nem é lar com texto de Dionísio Toleto e fotos de Pedro Flores exatamente sobre esse assunto (TOLEDO; FLORES, 1953: 48-50,56).

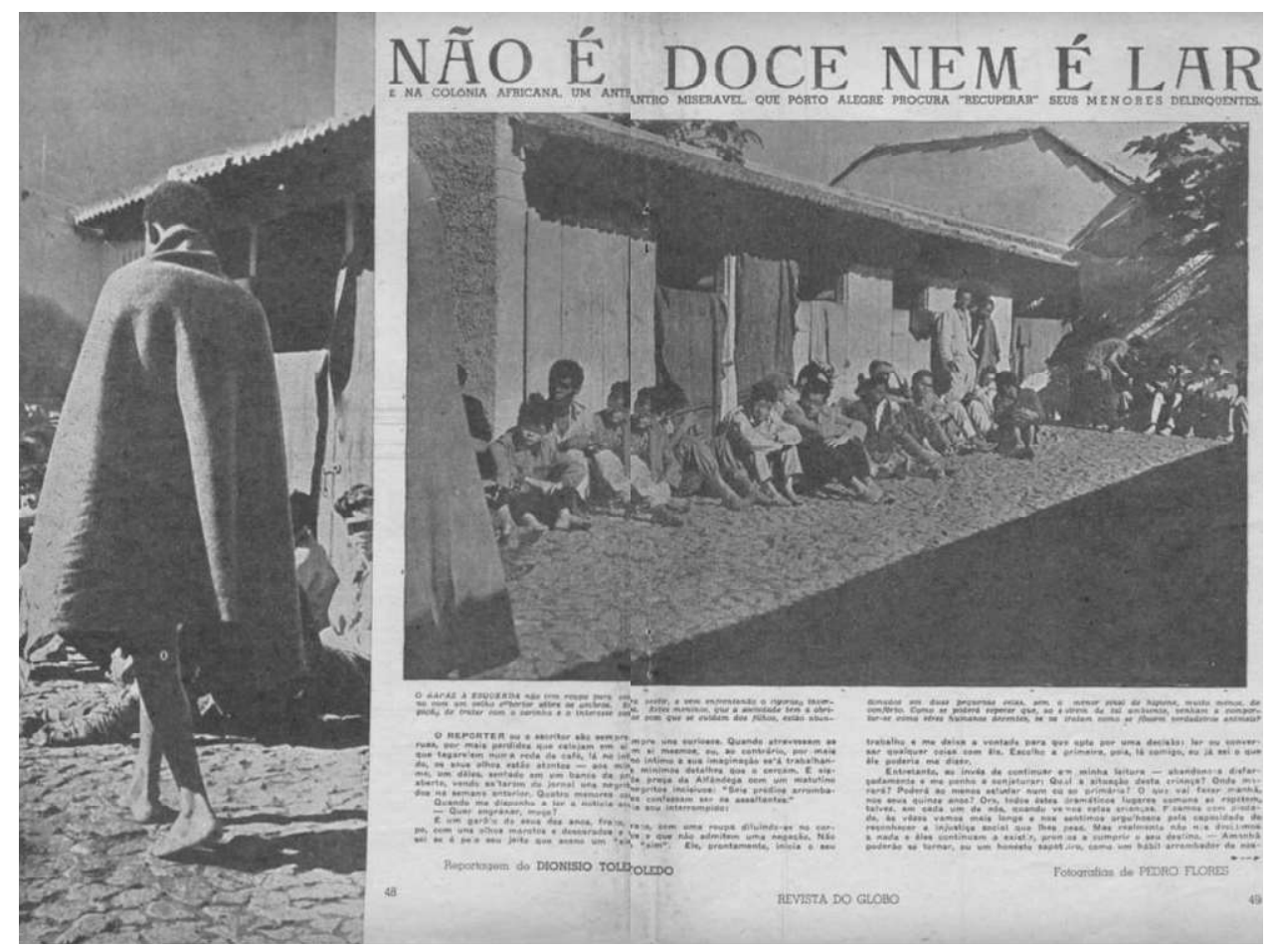

Imagem 2. Fonte: TOLEDO, D.; FLORES, P. (1953). Não é doce nem é lar. In: Revista do Globo, n. $616,10 / 07 / 1953$, p. $48-49$.

A fotorreportagem tem três páginas com cinco fotografias, iniciando-se com página dupla com duas fotos de formato grande (com mais de meia página) e 
continuando na terceira página com três fotos de formato pequeno com menos de $1 / 4$ de página. Nas primeiras duas páginas, na abertura da fotorreportagem, apresentam-se fotografias de grande formato com tom sensacionalista visando causar impacto e despertar a atenção do leitor.

A primeira foto no formato retangular vertical apresenta em primeiro plano um jovem negro de costas, enrolado em um cobertor, descalço e caminhando sobre as pedras irregulares de um pátio e ao fundo, em segundo plano, uma fileira de jovens sentados no chão (com tarjas pretas cobrindo os olhos) diante de uma casa térrea de madeira com beiral. Ao lado, a segunda foto apresenta em primeiro plano um pátio com chão de pedras, sobre o qual se projeta uma larga sombra, no qual se encontra um grupo de jovens sentados no chão lado a lado em fila (dois deles se destacam por estarem em pé) em frente a uma casa de madeira e de telhado baixo com três aberturas de onde pendem cobertores. Vê-se ainda, ao fundo, um fragmento de céu, a parede de outra casa e a copa de uma árvore que projeta sua sombra sobre o pátio, onde quatro jovens se encontram sentados contra a parede. Observa-se, por um fragmento do cobertor nas costas do jovem da primeira fotografia que aparece na segunda fotografia, que se trata do mesmo lugar e que essas se complementam enfocando os dois lados do mesmo pátio. $O$ que permite ver a casa ao fundo e um grande grupo de jovens sentados no chão do pátio ora mais de perto e ora mais de longe em seu conjunto.

$\mathrm{Na}$ página seguinte, três fotografias de formato pequeno complementam e detalham alguns aspectos das duas imagens anteriores. No alto da página, a terceira foto apresenta uma parede rústica com uma prateleira, onde se observa uma fileira de latas, abaixo dela um banco de tábuas e em cima dele um tacho de leite vazio virado. Na quarta foto, quatro jovens dormem amontoados no chão no canto de uma peça enrolados em panos. Na última foto, em baixo da página, um jovem num pátio de pedras revirando um monte de panos empilhados numa tábua sobre cavalete encostados contra um canto de parede onde se observa uma janela com uma grade feita de barras de ferro sobrepostas. No plano icônico (de conteúdo), observa-se a repetição da idéia de empilhamento dos jovens sentados no chão, dormindo num quanto de peça, dos panos sobre um cavalete e das latas. Os significados de rusticidade do chão de pedras, da casa de madeira, das paredes rugosas da pilha de panos e das latas. A casa térrea de uma água que lembra o 
espaço rural e o passado colonial em oposição à casa burguesa e aos prédios de apartamentos de alto gabarito que dominam a representação da cidade em outras fotorreportagens. Os significados de abandono e a anomia são explorados através da apresentação dos jovens sentados contra a parede ou deitados no chão, bem como a pobreza das suas vestes e do lugar que se encontram.

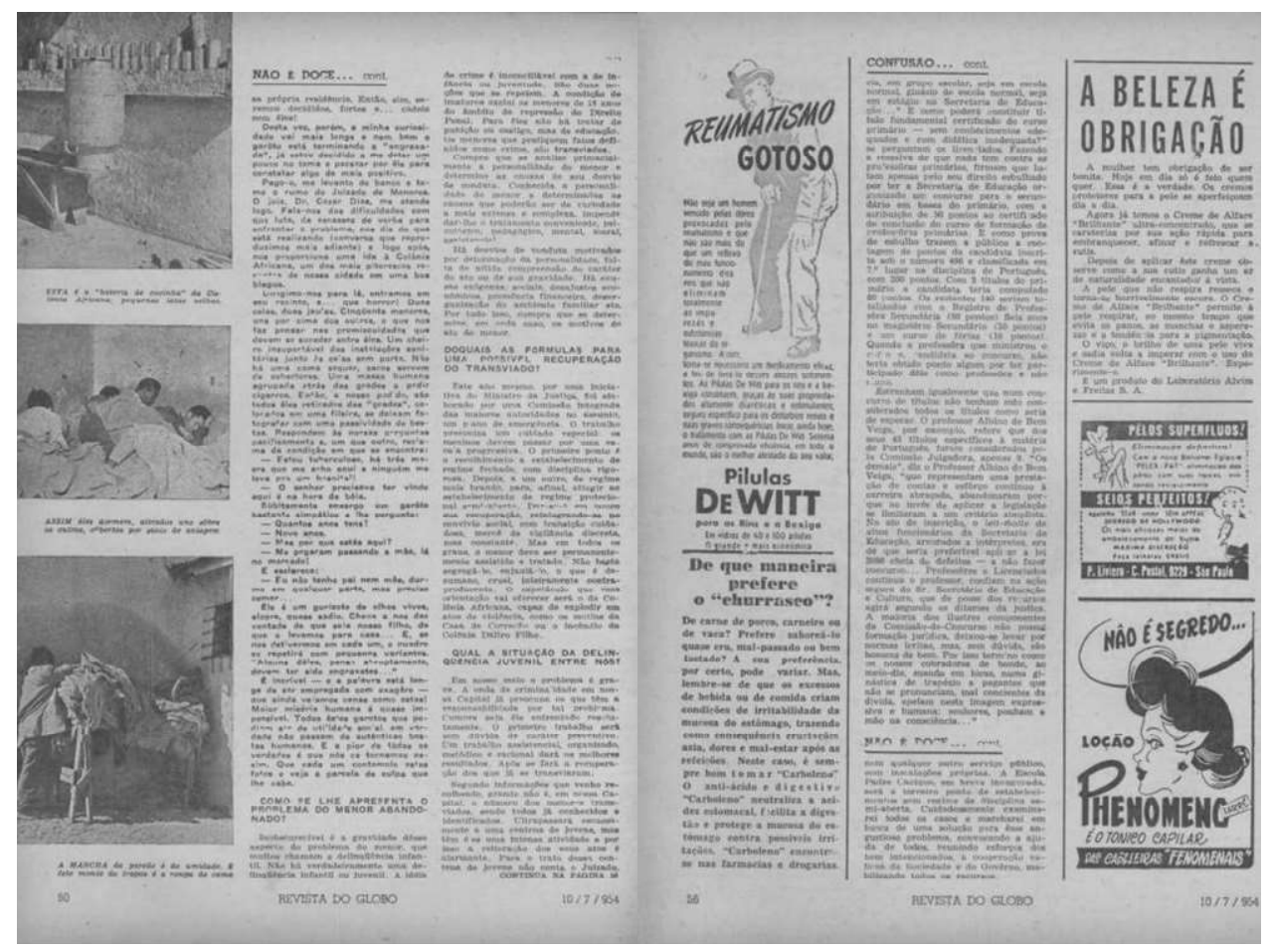

Imagem 3. Fonte: TOLEDO, D.; FLORES, P. (1953). Não é doce nem é lar. In: Revista do Globo, n. 616, 10/07/1953, p. 50, 56.

A análise formal (de expressão) das imagens aponta para escolhas de enquadramento e luminosidade que ampliam esses significados de pobreza, rusticidade e abandono. Nas duas primeiras fotos de grande formato, a câmera baixa (próxima ao chão) coloca em primeiro plano o piso do pátio de pedras irregulares, sobre o qual se projetam largas sombras, focando os pés descalços dos jovens. A seqüência narrativa das fotos começa no exterior e penetra no interior rústico da habitação apresentando detalhes que complementam os significados de pobreza, rusticidade e abandono. 
Estamos na esfera do visível dos dispositivos do olhar do poder, da visão policial, que esquadrinha e dá a ver o outro, que torna o visível para reificá-lo, que o transforma em objeto, em coisa. A revista dá a ver o "outro" - o jovem, negro, pobre, condenado pela justiça - na sua miséria e na sua diferença em relação ao padrão burguês de habitação e consumo da cidade moderna. Desvalorizando-o e estigmatizando-o em relação às esferas do trabalho e do ordenamento social que caracterizam as representações da cidade moderna e das classes alinhadas com esse projeto de modernização.

Os títulos, legendas e textos ampliam essa representação e colaboram para construir uma imagem de alteridade negativa destes jovens relacionado a certos espaços da cidade. Observe-se o subtítulo da fotorreportagem: "É na Colônia Africana, um antro miserável, que Porto Alegre procura 'recuperar' seus menores delinqüentes" (TOLEDO; FLORES, 1953: 48-49). Nesse subtítulo associa-se a representação desses jovens com os significados de colônia (penal ou período colonial?), de africana (estrangeira? negro?), de miserável e de delinqüência, localizados em determinado espaço urbano e que se opõe ao conjunto da cidade de Porto Alegre.

A fotorreportagem adquire tom de fotonovela pela forma como a narrativa é conduzida em primeira pessoa seguindo os passos do repórter que procura desvendar o problema do jovem e criança de rua em Porto Alegre. O texto começa com uma caminhada da personagem-repórter pelo centro da cidade a deparar-se com as manchetes dos jornais a noticiar o arrombamento de seis prédios. Depois, em um fluxo de consciência, a personagem pensa na possibilidade de sua residência ser arrombada e na sua vontade de ver os responsáveis na cadeia. Na seqüência depara-se com uma criança oferecendo-se para engraxar os seus sapatos, aceita e passa a pensar no problema dos jovens delinqüentes da cidade. $O$ fato o leva a querer investigar o assunto. Ele se dirige à autoridade competente do Juizado de Menores, que lhe fala do problema da escassez de verbas e se oferece para conduzi-lo a um passeio visando conhecer uma instituição que abriga jovens e crianças na Colônia Africana. Cabe salientar que essa forma de narrativa (próxima ao antigo folhetim e a fotonovela) visa desperta o interesse dos leitores e colocálos ao lado do repórter em sua "pesquisa". A descrição da instituição pelo personagem repórter e bastante forte e entremeada de qualificativos: 
Dirigimos-nos para lá, entramos em seu recinto, e ... que horror! Duas celas, duas jaulas. Cinqüenta menores, uns sobre os outros, o que nos faz pensar nas promiscuidades que devem se sucede entre eles. Um cheiro insuportável das instalações sanitárias junto as celas sem porta. Não há uma cama sequer, sacos servem de cobertores. Uma massa humana agrupada atrás das grades a pedir cigarros. Então a nosso pedido, são todos eles retirados das "grades", colocados em uma fileira, se deixam fotografar com uma passividade de bestas. (Id.,ib.: 50)

Descobre-se, então, que a fotografia foi armada e os jovens posaram para ela segundo a lógica da fotografia policial de identificação do criminoso, do outro, do excluído. A avaliação da revista é tanto estética quanto moral sobre o lugar e as pessoas que lá se encontram. "Lá" na Colônia Africana, tudo se opõe a moral, a estética e aos padrões sociais civilizados (poder-se-ia dizer burgueses?) que o repórter e os leitores defendem na "cidade". Mais adiante, o repórter-personagem completa o processo de estigmatização desse "outro": "Todos esses garotos que podiam ser de utilidade social em verdade não passam de autênticas bestas (sic) humanas" (Id.,ib.: 50).

Apesar de certo humanismo que leva o repórter a associar aqueles jovens ao engraxate que encontrou no centro e da vontade "de que seja nosso próprio filho, que o levemos para cassa..." (Id.,ib., 1953: 50), a reportagem defende um conjunto de medidas de caráter preventivo das autoridades que permitissem identificar, avaliar, encaminhar e tratar esses jovens visando a sua recuperação e reintegração no convívio social. Para tanto, poder-se-ia utilizar o regime semiaberto, sob vigilância discreta, mas constante. O que remete a próxima fotorreportagem sobre uma nova instituição para o recolhimento e reeducação de jovens infratores.

A fotorreportagem $O$ lar para o pequeno marginal ${ }^{4}$ (GOULART; GUERREIRO, 1957: 36-51), de 24 de agosto de 1957, com texto de Antônio Goulart e fotografias de Léo Guerreiro, é composta de seis páginas e sete fotos P\&B: duas fotos grandes com formato de retângulo horizontal, três fotos de tamanho médio (uma no formato retângulo vertical e outras duas no formato retângulo horizontal) e duas fotos pequenas no formato quadrado.

\footnotetext{
4 GOULART, A.; GUERREIRO, L. O novo lar para o pequeno marginal. In: Revista do Globo, n. 697, 6/9/1957, p. 36-41.
} 


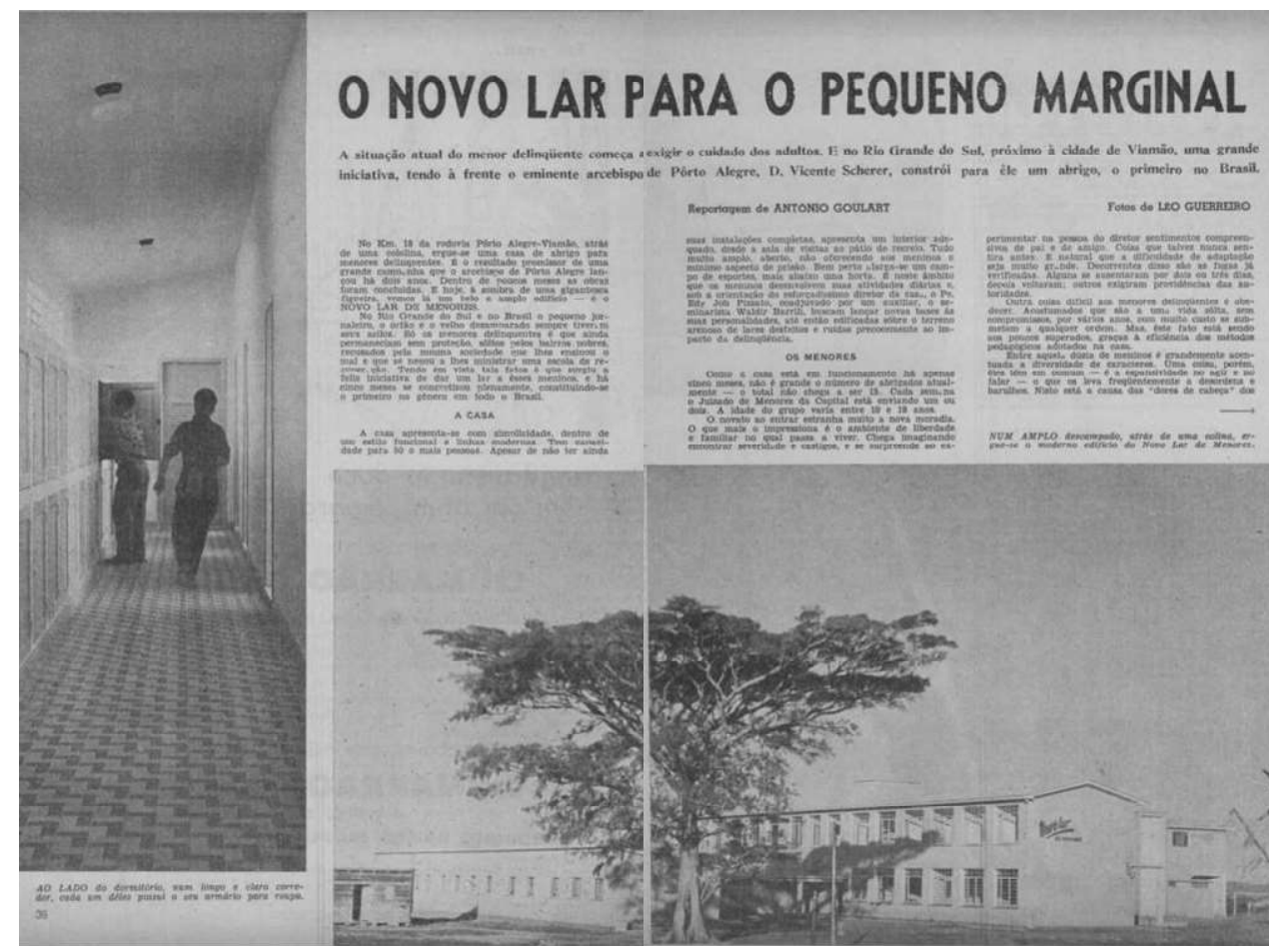

Imagem 4. Fonte: GOULART, A.; GUERREIRO, L. (1957) O novo lar para o pequeno marginal. In: Revista do Globo, n. 697, 6/9/1957, p. 36,37.

Ela começa em página dupla com uma fotografia retangular na vertical um pouco menor do que meia página. Nela se pode observar dois rapazes no fundo de um longo corredor. Em primeiro plano, destaca-se o piso de ladrilhos de duas cores em "L"; em segundo plano, um jovem de costas caminha em direção ao fundo do corredor e caminha em frente a três portas abertas de onde se projeta uma luz sobre a parede contrária cheia de portas de armários fechadas; um pouco a frente e a esquerda, outro rapaz procura algo dentro de um armário com a porta aberta. No teto de cor clara, como as paredes laterais, observam-se duas luminárias. Não se observam objetos no chão ou nas paredes.

No aspecto formal, a foto tirada em ângulo de 90 graus com o chão, que ocupa o primeiro plano e com os jovens ao fundo em segundo plano, destaca a profundidade e a amplidão do corredor; a seqüência de portas de armários e de portas abertas dá ritmo, ordenação e equilíbrio à imagem. A fotografia constrói significados de ordem, limpeza e amplitude do espaço. O que é reafirmado pela legenda "Ao lado do dormitório, num longo e claro corredor, cada um deles possui 
o seu armário para roupa" ${ }^{5}$. A segunda foto é uma vista parcial que, em primeiro plano apresenta uma grande árvore e, em segundo plano, em toda a sua extensão um longo edifício de dois andares, em terceiro plano, o céu ocupa boa parte do espaço da fotografia.

No plano formal, observa-se que o fotografo construiu uma foto tirada a distância para enquadrar a árvore alta que se sobrepõe e projeta a sua sombra sobre o longo prédio de dois andares com uma generosa porção de céu ao fundo. A árvore alta parece proteger o edifício novo ao projetar sua sombra sobre ele. A tomada à distância enfatiza o tamanho do prédio e sua integração com a natureza (árvore e céu) construindo significados de salubridade e amplidão. O que também é destacado na legenda e no início do texto da fotorreportagem: "Num amplo descampado, atrás de uma colina, ergue-se o moderno edifício do Novo Lar de Menores" (Id., ib.: 37). O adjetivo moderno coloca-o em sintonia com os objetivos reiterados da revista de ser porta-voz do homem e da mulher moderna. No terceiro parágrafo descreve-se o Novo Lar:

A casa apresenta-se com simplicidade, dentro de um estilo funcional e linhas modernas. Têm capacidade para 50 ou mãos pessoas. Apesar de não ter ainda suas instalações completas, apresenta um interior adequado, desde a sala de visitas ao pátio de recreio. Tudo muito amplo, aberto, não oferecendo aos meninos o mínimo aspecto de prisão. Bem perto se alarga um campo de esportes, mais abaixo uma horta (id., ib.: 37 ).

As fotografias e o texto complementam-se na apresentação das instalações e das atividades que se desenvolvem na instituição. Nesse sentido as fotos têm o papel de testemunhar e certificar a veracidade e a exatidão da descrição, como se observa na seqüência de cinco fotos que complementam a fotorreportagem, testemunhando e detalhando atividades de trabalho e de lazer dos meninos na instituição. Na segunda página a terceira foto enquadra em primeiro plano um menino de costa no gol observando três outros garotos disputando a bola a alguns metros á frente, no segundo plano. Num terceiro plano, apresenta-se a amplidão de um campo aberto e morros ao fundo, muito além dos limites do campo de futebol onde os meninos jogam bola. No foto abaixo dessa, apresenta-se em primeiro plano dois meninos carregando enxadas, em segundo plano, mais a frente dois homens também carregando ferramentas (o primeiro deles de roupa preta,

\footnotetext{
${ }^{5}$ Idem, p. 36.
} 
que aparenta ser um padre de batina) e, mais além, observa-se o prédio da instituição e a amplidão do céu. No plano icônico de conteúdo, as duas fotos apresentam a união de lazer e trabalho, ambas as atividades desenvolvidas ao ar livre e em contato com a natureza (campo, árvores, céu). Por isso, muito saudáveis e apropriadas a esses jovens. O que é complementado pelo subtítulo ao lado "Apreciam esporte e trabalho" (Id., ib.: 38).

No formal da expressão, estas vistas parciais da instituição com grande profundidade de campo e enquadramento do céu (representa entre $1 / 3$ e 1/2 das fotografias respectivamente) apontam para a vida em contato com a natureza, liberdade, salubridade, num ambiente com harmonia e paz ideal para o desenvolvimento dos jovens.

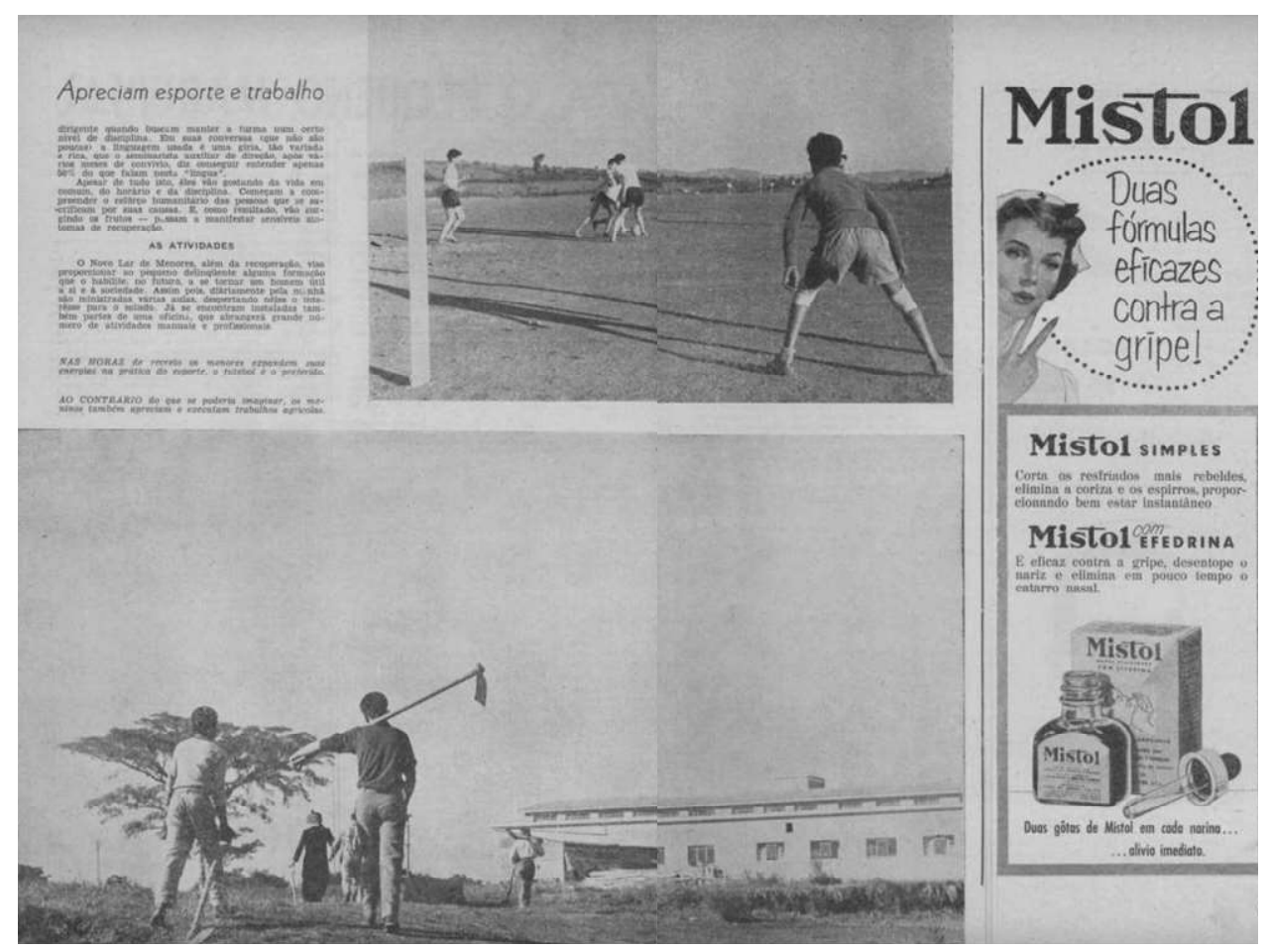

Imagem 5. Fonte: GOULART, A.; GUERREIRO, L. (1957) O novo lar para o pequeno marginal. In: Revista do Globo, n. 697, 6/9/1957, p. 38,39.

Outras três imagens complementam esses significados nas duas páginas seguintes que concluem a reportagem (Id., ib. : 40,41). As fotos, o subtítulo e as legendas concorrem com as publicidades que ocupam a metade externa dessas páginas. A quinta fotografia apresenta um grupo de jovens/meninos ao redor de 
uma mesa em um ambiente amplo. Em primeiro plano, um menino está se levantando na ponta da mesa e outro está de pé no lado esquerdo, um homem de pé parecer ser um padre usando batina preta, outros três meninos estão sentados e outros dois mais ao fundo parecem estar de pé atrás da mesa. Em um segundo plano, ao fundo da sala ampla armários na parede e uma porta aberta para outro aposento. A legenda esclarece: "No refeitório este grupo, sem nenhuma cerimônia, mistura no café da tarde conversa e risadas gostosas". A foto é um instantâneo, a análise icônica sugere o binômio formado pela amplidão da sala e a unidade do grupo ao redor da mesa para a refeição. A descontração do grupo é vigiado e controlado pelo padre ao fundo, que representa a autoridade e a ordem na instituição. O grupo que está bem centralizado e em foco é núcleo significante da imagem. O contraste entre a luminosidade clara da sala e os tons mais escuros das roupas dos meninos do grupo ao redor da mesa complementa esse significado de unidade do grupo.

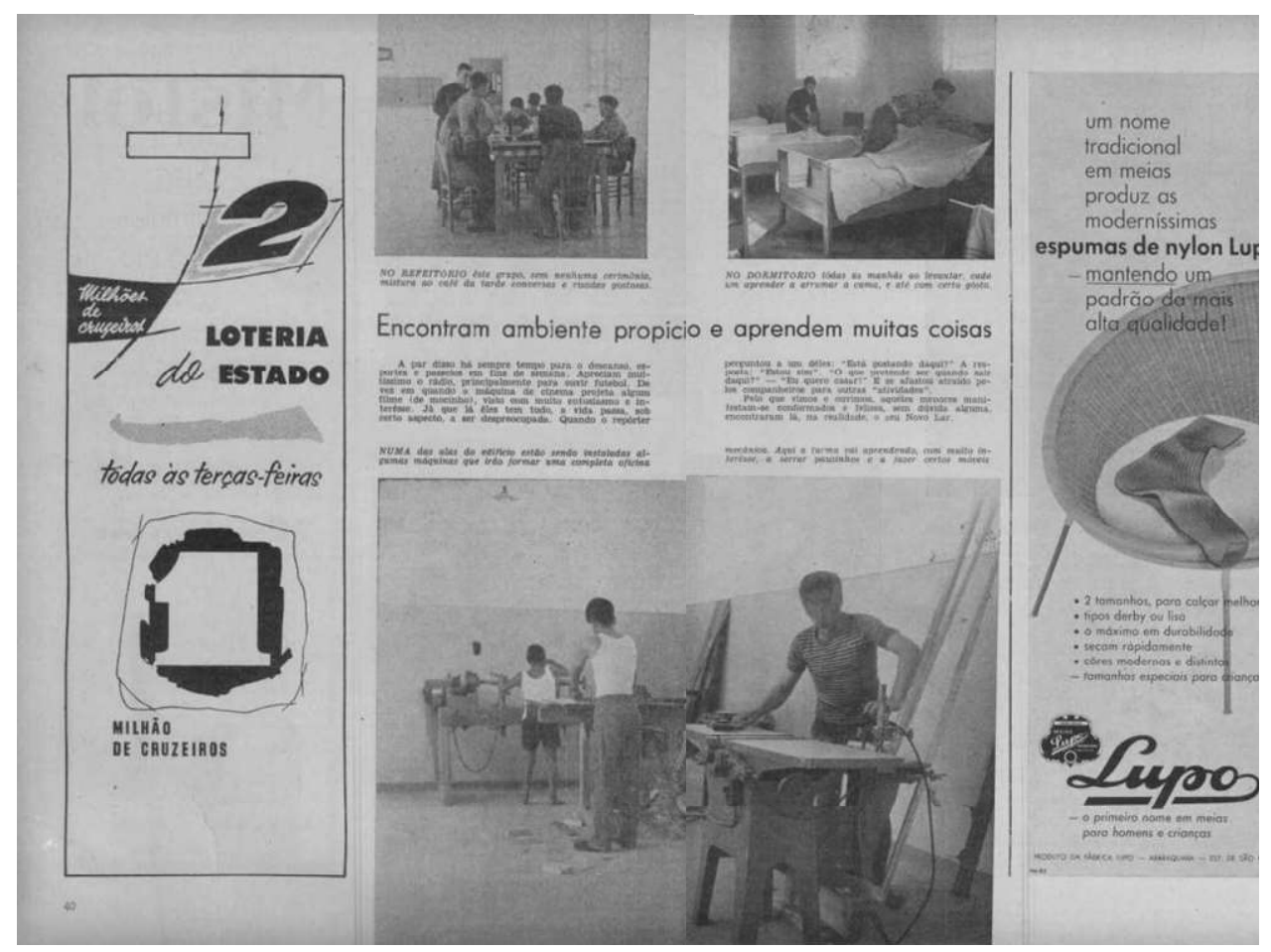

Imagem 6. Fonte: GOULART, A.; GUERREIRO, L. (1957) O novo lar para o pequeno marginal. In: Revista do Globo, n. 697,6/9/1957, p. 40,41. 
Ao lado dessa fotografia, uma outra apresenta dois meninos em um dormitório arrumando as suas camas. As roupas de cama parecem bem brancas e uma luminosidade forte entra através das duas janelas abertas sobre as camas. É um instantâneo ou foto posada? Não se pode saber ao certo, mas tudo indica a pose. Novamente, a análise icônica aponta para a construção de significados de responsabilidade, disciplina, ordem, higiene e bem estar dos meninos na instituição. A análise formal permite ver no enquadramento de três camas e duas janelas um arranjo equilibrado indicando repetição e equilíbrio, embora a postura do corpo dos meninos indique movimento e dinamismo. A foto tirada na contraluz coloca em relevo a luminosidade que entra pelas duas janelas e ilumina o dormitório e os lençóis brancos ajudando a construir a idéia de um ambiente higiênico e saudável para viver. O que é reforçado pelo subtítulo em destaque no meio da página: "Encontram ambiente propício e aprendem muitas coisas"6.

Embaixo, na mesma página, uma fotografia média em formato retangular horizontal representa dois jovens e um menino operando maquinas sobre bancadas de ferro e madeira num ambiente que parece ser uma oficina. Em primeiro plano à direita, observa-se um jovem de frente para a câmera (porém seu rosto foi borrado, provavelmente no negativo antes da ampliação, para preservar a sua identidade) operando uma ferramenta elétrica com a mão esquerda e pousando a mão direita sobre outra em cima da bancada. Em segundo plano, outro jovem de costas opera uma máquina sobre outra bancada. Um pouco mais ao fundo um menino, também de costas, também parece operar uma máquina sobre uma bancada. A oficina afigura-se ampla e clara (pintada em duas cores, uma cor até um metro e meio do chão e outra mais clara daí para cima até o teto), do teto pende uma luminária sobre a segunda bancada. No chão, alguns objetos caídos são os restos da ação do trabalho executado à máquina pelo segundo jovem. A legenda esclarece tratar-se uma oficina de marcenaria onde se fabricam móveis.

No plano icônico, essa imagem encerra a fotorreportagem com os significados do trabalho, da operosidade, da produtividade com complemento e ponto culminante do trabalho de reabilitação e re-socialização dos "pequenos marginais" (sic). A narrativa visual ordenada nos leva a um passeio pela instituição: começamos a distância contemplando o terreno, a modernidade e o

\footnotetext{
${ }^{6}$ Idem, p. 40-41.
} 
tamanho do prédio, bem como sua localização favorável em meio a natureza; depois passamos ao campo de futebol; e ainda a volta do trabalho da horta; no interior observamos o refeitório, os quartos e a oficina. Tudo muito limpo, espaçoso, ordenado e iluminado para a reabilitação dos meninos e jovens sobre o olhar atento e vigilante do padre e seu assistente. Há um processo de acumulação e de reforço dos significados das imagens anteriores de forma bastante pedagógica para o leitor da revista visando apresentar-lhes os benefícios da reclusão, do trabalho, da disciplina e do trabalho para a reabilitação e re-inserção social desses jovens e meninos.

Essas reportagens encerram todo um percurso e uma discussão sobre o lugar da criança e do jovem de rua na cidade moderna. Na primeira reportagem o leitor é informado da sua periculosidade e dos inúmeros roubos por eles cometidos, fazendo-os figurar como ameaça número um à propriedade. $\mathrm{Na}$ segunda reportagem, a revista focaliza os jovens vivendo quase como animais em um antro na periferia da cidade: a Colônia Africana. Finalmente, a última reportagem, apresenta a solução do problema com o distanciamento desses jovens e meninos da cidade grande nos áreas saudáveis e m contato com a natureza de Viamão no "Novo Lar do Menor". Onde, em um ambiente saudável, limpo, arejado e disciplinado, isolado dos maus da cidade, eles aprenderam a trabalhar na horta, na oficina e receberão cama, comida, roupas e educação profissional para se tornarem indivíduos úteis e prontos para se re-inserirem na sociedade moderna.

Logo, a todo um processo de estigmatização desses jovens e crianças de rua, exigindo seu afastamento dos antros das periferias (verdadeiras escolas do crime) e sua segregação em espaços afastados da cidade, em meio a natureza, visando a sua disciplinarização, recuperação e futura re-inserção na sociedade através do mundo do trabalho.

Através dessas fotorreportagens a revista se engajou no projeto de modernidade e de modernização da cidade através da construção de uma nova visualidade. Essa nova visualidade urbana jogou tanto com significados sociais de inclusão e legitimação da ação de certos atores e grupos sociais no espaço urbano quanto de exclusão e estigmatização da ação e da presença de outros sujeitos e grupos sociais na cidade em processo de modernização. Este é o caso dos jovens e 
crianças de rua, infratoras ou não, que passavam a ser identificadas como uma ameaça à propriedade e à ordem social.

As fotografias ajudavam a dar visibilidade à ação da polícia no combate ao crime e construírem uma imagem negativa desses jovens e dos espaços urbanos a eles associados na cidade: as vilas periféricas. Elas construíam hierarquias e diferenças sociais, produzindo a estigmatização e a segregação desses sujeitos no espaço urbano. Elas terminavam reforçando e legitimando o processo de afastamento desses grupos para áreas distantes dos espaços centrais onde imperaria a lógica da modernidade, da sociedade de consumo e da especulação imobiliária. O processo de construção de identidades ou de identificações sociais passa pela definição de práticas modernas e seu avesso, constituindo a alteridade. A necessidade de exclusão e de disciplinamento dos jovens de rua aparece de forma clara nas páginas das fotorreportagens, sendo construída pelas falas das autoridades polícias e pela forma como a revista alçada a condição de porta voz da sociedade porto-alegrense construía a sua imagem. A imagem destes jovens e crianças em situação de rua fazia estilhaçar o espelho onde se projetava a nova imagem de cidade em construção no espaço urbano e em elaboração nas páginas da Revista do Globo. Logo, essa imagem exigia uma elaboração e um tratamento para que não ferisse a nova sensibilidade ou o novo padrão visual de cidade moderna consumida pelas elites e camadas médias. A nova visualidade urbana construída na revista permite uma série de recursos (editoração, paginação, narrativa, etc.) para elaborar e disciplinar essa imagem do outro e faze - lá reforçar os significados sociais ligados à modernidade: visibilidade, ordenamento e dinamicidade entre outros.

Nesse sentido, a análise dessas fotorreportagens permite problematizar a construção de um padrão visualidade urbana e o discurso de modernidade social das revistas ilustradas. Elas fazem pensar sobre a forma excludente e hierárquica como é construída a imagem dos "outros" sujeitos sociais, que terminam sendo apenas objetos do olhar disciplinador das elites que os coisifica, tornando-os alvo de políticas públicas e não sujeitos sociais com direitos civis e demandas políticas no processo de construção social do espaço urbano. 


\section{Referências bibliográficas:}

COSTA, Helouise (1992). A fotografia de imprensa: diferentes determinações para a imprensa diária e para os semanários. In: Aprenda a ver as coisas: Fotojornalismo e Modernidade na revista O Cruzeiro. Dissertação (Mestrado) - Escola de Comunicações e Artes, Universidade de São Paulo, São Paulo. pp. 53-68.

GOULART, A.; GUERREIRO, L. (1957) O novo lar para o pequeno marginal. In: Revista do Globo, n. 697, 6/9/1957, p. 36-41.

KNAUS, Paulo (2006). O desafio de fazer história com imagens: arte e cultura visual. In: ArtCultura, UFU, vol. 8, n. 12, jan. - jun., p. 97-115.

LIMA, Solange Ferraz de; CARVALHO, Vânia Carneiro de (1997). Fotografia e cidade. Da razão urbana à lógica de consumo. Álbuns de São Paulo (1887-1954). Campinhas, SP: Mercado das Letras; São Paulo: FAPESP.

MAUAD, Ana Maria. Sob o signo da imagem: a produção da fotografia e o controle dos códigos de representação social da classe dominante no Rio de Janeiro na primeira metade do século XX. Tese de Doutorado. Orientação de Raquel Soihet. Niterói: UFF, 1990.

MAUAD, Ana Maria (2005). Na mira do olhar: um exercício de análise da fotografia nas revistas ilustradas cariocas, na primeira metade do século $X X$. Anais do Museu Paulista, São Paulo, Brasil, v. 13, n.01, p. 133-174, jan.-jun.

MENESES, Ulpiano Bezerra de (2003). Fontes visuais, cultura visual, história visual: balanço provisório, propostas cautelares. In: O ofício do historiador, Revista Brasileira de História, vol. 23, n.o 45, jul. 2003, p. 11-36.

MENESES, Ulpiano T Bezerra de (2005). Rumo a uma "História Visual". In: MARTINS, J. S.; ECKERT, C.; NOVAES, S. C. (orgs.). O imaginário e o poético nas Ciencias Sociais. Bauru, SP: EDUSC, p. 33-56.

MICHELON, Francisca Ferreira (2001). Cidade de Papel: a modernidade nas fotografias impressas de Pelotas (1913-1930). Porto Alegre. 547 f. Tese (Doutorado) - Programa de Pós-Graduação em História, Pontifícia Universidade Católica do Rio Grande do Sul.

MONTEIRO, Charles (2007). Imagens sedutoras da modernidade urbana: reflexões sobre a construção de um novo padrão de visualidade urbana nas 
revistas ilustradas na década de 1950. In: Revista Brasileira de História, vol. 27, n. 53, 2007, p. 159-176.

POSSAMAI, Zita R (2005). Cidade Fotografada: memória e esquecimento nos álbuns fotográficos - Porto Alegre, décadas de 1920 e 1930. Porto Alegre. Tese (Doutorado em História) - Faculdade de Filosofia e Ciências Humanas Universidade Federal do Rio Grande do Sul. 2 vol.

TAJES, T.; FlORES, P.; CAVAlHEIRO, W. (1953). Porto Alegre: Uma cidade entregue aos ladrões. In: Revista do Globo, n. 580, 21/02/1953, p. 60, 61, 66.

TOLEDO, D.; FLORES, P. (1953). Não é doce nem é lar. In: Revista do Globo, n. $616,10 / 07 / 1953$, p. 48-50, 56.

WOODWARD, K (2000). Identidade e diferença: uma introdução teórica e conceitual. In: SILVA, T. T. (org.). Identidade e diferença: a perspectiva dos estudos culturais. Petrópolis: Vozes.

Texto recebido em 18/9/2007. 